\title{
MANAJEMEN PENGELOLAAN HARTA KEKAYAAN PADA PENGUSAHA MUSLIM DI MARTAPURA PERSPEKTIF EKONOMI SYARIAH
}

\author{
Akhmad Hulaify \\ Email: hulaify@gmail.com \\ Syahrani \\ Email: syahranibjm@yahoo.com \\ Universitas Islam Kalimantan (UNISKA) MAB Banjarmasin
}

\begin{abstract}
Wealth management in moslem's enterprenuer at Martapura is an orientation of this research. Besed on wealth management concept, the researcher try to explore how is their the wealth management concept so that their wealth bring blessings. The aim of this research to gire more explanation related on wealth management concept that done by moslem's enterprenuer at Martapura. This research is a field research. Because of this research choices Martapura Kabupaten Banjar, so for reveling the problem, research apply sosiologic normative approach. in revaling and analyze the problem, research apply qualitative description opproach. So will found the answer from real condition that happened in the field. A series of those process make a description that thereaded (concatenated description) so easy to understand. The cunclosion of this research is moslem's enterprenuer at Martapura have wealth management concept the oriented to Allah SWT's blessings. So the steep and management schemesthat they did in eccordance with syari's laws. But in orther side, there are several things that need to be anhanched aspecially, related to the management of incoe rest. They have preference in using to distribute directty better to allocated their fund in long term investment. So concept "Falah" in syariah economic understanding can be reached.
\end{abstract}

Keywords : Management, Wealth, Moslem's, Enterprenuers. 


\section{PENDAHULUAN}

Peradaban manusia membawa dampak dalam perkembangan pola pemikiran. Dampak tersebut baik itu bersifat postif maupun berdampak negative. Dampak positif berupa perkembangan pemikiran yang mengarah kepada kecermatan dalam menganalisa permasalahan serta memberikan jawaban terhadap permasalahan baik itu bersifat temporal maupun jangka panjang.

Seiring kondisi tersebut Islam sejak lama sudah memberikan dasar pijakan dalam menjawab permasalahan yang muncul dalam masyarakat agar tirhindar dari kerugian dan masalah dalam kehidupan. Jawaban atas permasalahan tersebut dapat kita temukan di dalam Al-Quran dan Hadits. Dasar tersebut termaktub dalam hadits yang diriwayatkan oleh Malik yang artinya:

"Telah aku tinggalkan pada kalian dua perkara, jika kalian berpegang teguh dengan keduanya kalian tidak akan sesat selama-lamanya yaitu Kitabullah dan Sunnah Nabi-Nya".
Merujuk kepada hadits tersebut tentunya kita sebagi umat Islam terselamatkan dari permasalahan yang ada di dunia dan akhirat. Tentunya jika kita berpegang teguh kepadanya. Dari sisi inilah kita harus berusaha mengkaji lebih dalam agar kita terhindar dari pelemik kehidupan yang bisa mengantarkan kepada kerugian yang jelas tergambar dalam $\mathrm{Al}$ Quran Surah Al' Ashr Ayat 1-3 yang artinya:

1. Demi Masa. 2. Sessungguhnya manusia berada dalam kerugian. 3. Kecuali orang-orang yang beriman dan mengerjakan kebajikan serta saling menasehati untuk kebenaran dan saling menasehati untuk kesabaran.

Meruntut dari penjalasan tersebut permasalahan tersebut harus di jawab dengan cara sabar, arif dan bijaksana. Jika kita tarik benang merah dari penjelasan di atas maka tidak lah kesusahan dalam mengatasi permasalahan yang muncul dalam kehidupan kita sehari-hari. Kejadian yang sering terjadi pada kehidupan kita adalah keteledoran kita mengkaji ulang 
tatkala kita menemukan permasalah untuk kembali kepada al Quran dan Al Hadits.

Oleh karena itu, dalam penelitian ini kami berkeinginan menelaah lebih dalam permasalahan yang muncul dalam kehidupan kita pada zaman sekarang. Dimana kondisi sekarang berbeda jauh dengan masa ke emasan Islam baik di masa Nabi Muhammad SAW dan kepada runtuhnya kejayaan Islam di masa Turki Usmani.

Problem-problem yang muncul tersebut kami cermati melalui bidang keilmuan kami yaitu Ekonomi Syariah dan Manajemen Syariah. Untuk ke konsistensi bidang ini tentuanya sangatlah luas pembahasannya. Oleh kerena itu kami akan mengkaji permasalahan Manajemen Pengelolaan Harta Kekayaan pada pera pelaku bisnis di masyarakat Martapura.

Melihat dari latar belakang masyarakat martapura yang mempunyai dasar agamis dan bisnis walaupun ada sebagian yang bertani dan berkebun. Kondisi tersebut di dukung oleh banyaknya ulama besar dan kaya raya kalau di lihat dari sisi ekonomi.

Dengan dasar tersebutlah kami tertarik untuk mengkaji lebih dalam bagaimana manajemen pengelolaan harta kekayaan pada masyarakat Martapura.

Berbagai kondisi permasalahan yang terjadi mengantarkan sudut pandang kami dalam melihat realitas kehidupan masyarakat Martapura yang agamis. Tentunya hal ini menarik untuk di kaji lebih dalam. Apalagi kalau di kaji dari sisi teori Manajemen dan Ekonomi Syariah. Realitas yang muncul dari sisi ekonomi masyarakat Martapura tentunya bisa diangkat menjadi sebuah bahan kajian yang layak dan pantas dalam perkembangan sisi keilmuan antara manajemen dan ekonomi syariah ke depan.

Budaya dan peradaban mempengaruhi pola pikir masyarakat martapura. Apalagi kota martapura benyak melahirkan ulama-ulama besar bahkan kebesarannya sampai keluar pulau 
bahkan dunia internasional. Latar belakang tersebut tentunya tidak menjadikan Martapura dipandang sebelah mata dalam kajian ke ilmuan khususnya ilmu yang berbasis Islam. Realitas terebut terhubung dan melekat kepada budaya dan peradaban masyarakat kota Martapura. Di sisi lain, ulama martapura tidak hanya berdakwah, untuk mencukupi kehidupan pribadi dan keluarga ulama Martapura juga berbisnis. Namun bisnis di sini dalam perspektif meraka bukanlah tujuan utama. Bisnis dijalani sebagai sunnatullah yang berorientasi kepada kehidupan akhirat.

Perspektif ini, mengantarkan pemahaman bisnis adalah sebagai sarana untuk meningkatkan ibadah kepada Allah SWT. Bisnis di pandang sebagai penupang dakwak dalam mengembangkan pesan syariat dengan niat semata-mata kerena Allah SWT. Dengan demikian bisnis tersbut mendatangkan barokah dan manfaat secara menyeluruh untuk kehidupan ummat Islam.

Bidang bisnis tersebutlah menjadikan ulama kaya raya dalam konteks materi. Numun harta dalam pandangan mereka bukanlah milik mereka seutuhnya. Sebagaimana di gambarkan dalam Ayat Al Quran Surah Al Baqarah ayat 267 yang artinya:

"Hai orang-orang yang beriman, nafkahlah (di jalan Allah) sebagian hasil dari usahamu yang baik-baik dan sebagian dari yang Kami keluarkan dari Bumi untuk kamu. Dan janganlah kamu memilih yang buruk-buruk lalu kamu nafkahkan daripadanya, padahal kamu sindiri tidak mau mengambilnya melainkan dengan memicingkan mata terhadapnya. Dan ketahuilah, bahwa Allah Maha Kaya lagi Maha Terpuji".

Ayat tersebut di atas dijadikan sandaran oleh mereka dalam mengelola dan mengembankan harta kekayaan. Harta merupakan anugrah yang menjadi hak milik seutuhnya yang dapat di miliki baik secara pribadi maupun kelompok. Penafsiran yang sejalan dengan Al Quran inilah menjadikan harta menjadi berkembang dan barokah. 
Beranjak dari kondisi dan mekanisme tersebut di atas, perlu adanya pemahaman yang sejalan dengan Al Quran dan Hadits agar terhidar dari penyakit tamak, kikir, ujub, dengki dan lain-lain. Harta identic sekali menjadikan manusia untuk lalai dan lupa. Oleh karene itu lewat kajian ini kami ingin mengungkap makna bagaimana pola dan mekanisme pengelolaan harta dalam pemahaman para ulama martapura yang bisa mendatangkan barokah di dunia dan akhirat.

Penyaluran harta di dalam alquran di jelaskan melalui bentuk distribusi kekayaan berupa Zakat, Infaq dan Shadaqoh. Realisasi inilah yang di jelaskan Allah melalui al Quran. Dengan dasar inilah heposisi awal dibangun dalam membimbing kami untuk melakukan penelitian.

Di samping bagaimana kosep pengelolaan harta penelitian ini di arahkan untuk mengkaji kerifan local yang bisa di angkat kepermukaan sehingga dapat menembah khazanah ke-ilmuan dalam kontek Manajemen dan Ekonomi Syariah.

Sebagaimana dalam nash-nash syariat dan pendapat para ulama bahwa dalam ketentuan mencari kekayaan hukumnya adalah boleh (mubagh). Hukum kebolehan di sini mengandung arti bahwa manusia dibolehkan syara' dalam mencari dan mengaturnya sebagaimana hukum yang mengikat atas kebolehan tersebut. Maksudnya adalah dibolehkannya mencari dan mengelola adalah harus sesuai dengan kaidah-kaidah yang di atur oleh syara'.

\section{METODE PENELITIAN}

Jenis penelitian yang kami lakukan tergolong kedalam jenis penelitian kualitatif serta berorientasi kepada penelitian lapangan. Model pendekatan yang kami gunakan adalah pendekatan normative sosiologis. Pendekatan normative digunakan untuk mengualas bagaimana pandangan hukum syara terkait ketentuan dalam pengelolaan harta kekayaan. Kemudian 
pendekatan sosiologis juga merupakan factor pendukung dikarenakan milihat kepada realitas kehidupan masyarakat kota Martapura yang agamis. Data yang digunakan disini di bagi menjadi dua yaitu data primer data skunder yang berpusat kepada para pengusaha yang dikategorikan sukses dalam perspektif masyakat. Metode pengumpulan data yang digunakan adalah observasi, wawancara dan dokumentasi. Setelah semuanya berjalan makan dalam tahapan akhir kami memilih model analysis analisis diskriptif dan penjelasan (explanation). Tidak hanya berhenti pada tahapan tersebut peneliti juga mengelaborasi dengan anisis dengan menggunakan pendekatan normative hal ini dikarenakan basisis dari penelitian ini adalah kalam konteks syariah. Gambaran umum yang dapat di gambarkan dari proses analisis ini adalah dengan tahapan memberikan diskripsi dari fenomena-fenomena yang ada dalam teks baik itu mengacu kepada data literature maupun data di lapangan. Dengan demikian akan ditemukan scenario dari kondisi real yang terjadi di lapangan. Serangkaian proses tersebut menjadikannya sebuah diskripsi yang terangkai (concatenated description) sehingga mudah di pahami (Abdullah Lam, 2015)

\section{PEMBAHASAN}

Konsep Manejemen Pengelolaa Harta dalam Ekonomi Islam

Konsep dasar terkait dengan hukum mencari kekayaan pada kebanyakan ulama hukum nya mubah (boleh). Namun sebagaimana yang dikemukakan oleh Abdullah Lam Ibn Ibrahim hukum mencari kekayaan terbagi ke dalam lima bagian:

1. Wajib.

Imam Muhammad bin Hasan Asy Syaibani berpendapat bahwa “....apabila dia memiliki keluarga yang menjadi tanggungannya seperti istri, anak-anak nya maka wajib atasnya untuk memenuhi kebutuhan mereka, dan apabila 
ia memiliki kedua orang tua yang berusia lanjut maka wajib atasnya untuk memenuhi kebutuhan mereka. ${ }^{1}$ Kemudian Ibn Taimiyah berpendapat "mencari kekayaan hukumnya wajib yaitu berlaku perkaraperkara yang harus dilakukan untuk menunaikan kewajibankewajiban. (Al-Syatibi, 1994)

2. Mustahabba (sunah). Muhammad bin Hasan Asy Syaibani berkata "selain kedua orang tua dari keluarga dan kerabat yang merupakan mahram, bukanlah kewajiban seseorang untuk menafkahi mereka, karena meraka tidak berhak mendapatkan nafkah darinya, selain karena kemurahan dan kebaikan saja. Namun, seseorang tetap disunahkan berusaha da bekerja untuk menafkahi kerabatnya, karena hal itu merupakan hubungan siaturrahmi yang hukumnya sunah dalam syara'. (Asy-Saibani, 1994).
3. Mubah.

Muhammad bin Hasan Asy Syaibani kemudian menjelaskan bahwa apabila seseorang telah memenuhi kewajiban yang telah di bebankan atas dalam hal mencari nafkah dan apabila telah terpenuhi harta tersebut maka apabila ia berusaha ataupun tidak maka itu tidak bukanlah apa-apa baginya maka dengan demikian maka hukum mubah atasnya. (Al-Syatibi, 1994).

4. Makruh.

Mencari harta di hukumkan menjadi makruh apabila harta benda tersebut menyebabkan seseorang meninggalkan ibadah-ibdah sunah serta menyebabkan terjerumus ke dalam perkara-perkara yang makruh. Dengan kata lain bahwa dengan mencari harta tersebut mengantarkan ia kepada perkara-perkara makruh. ${ }^{2}$

5. Haram. 
Ibnu Katsir bependapat bahwa apabila seseorang dengan hartanya dapat menyebabkan ia berubah menjadi sombong, membangga-banggakan dan mempunyai tujuan lain yang mengjerumuskan kedalam perkara-perkara haram, maka hukum atasnya adalah haram. (Asy-Saibani, 1994)

Dengan demikian bahwasanya kedudukan mencari harta tidak lepas dari tuntunan syara' yang mana maksudnya dalah untuk menjadikan para pencari harta tidak menjadi terjerumus kepada hawa nafsu sehingga menjadikan harta tersebut tidak membawa berkah dalam pemanfaatannya.

Kajian Islam yang berkenaan konsep pengelolaan harta dapat kita telusuri pada salah satu tokoh pemikir Islam yaitu Ibnu Sinā. Pada pemikiran beliau bahawa harta atau kekayaan yang dapat dilakukan oleh manusia terbagi dalam dua kategori:
a. Mencari kekayaan serta mendapatkan kekayaan (kasb)

yang dikenal dengan istilah ekonomi disebut pendapatan.

b. Menggunakan kekayaan serta membelanjakan kekayaan yang diperoleh atau yang dikenal dengan istilah ekonomi sebagai pengeluaran (infaq). (AsySaibani, 1994).

Kegitan tersebut tentunya harus dilakukan dengan cara yang sesuai dengan aturan-aturan syara' seperti yang disebutkan Ibnu Sina dalam buku politiknya bahwa "hidup manusia harus diperoleh dengan cara yang benar dan baik, dan jauh dari sifat tamak dan pelit dan dari keinginan yang tamak dan rakus".

Kemudian Ibnu Sinā juga menjelaskan

pembagian pengeluaran(infaq), dimana jenis-jenis infaq dinyatakan sebagai berikut:

"Jika manusia memperoleh kekayaan hanya dengan cara yang baik, maka ia harus membelanjakan atau mengeluarkan sebagian dari kekayaannya untuk shodaqoh, zakat, kebajikan yang baik (alma'ruf), dan sebagian yang 
lain harus disimpan untuk masa depan dikarenakan peristiwaperistiwa mendesak yang terjadi berlaku pada masa itu". (AsySaibani, 1994).

Hal ini selaras dengan konsep syara', dimana manusia bisa mengkonsumsi apa yang dia miliki sesuai dengan kebutuhannya. Kemudian sisa pendapatan atau kekayaannya yang telah dikeluarkan sesuai dengan kebutuhan harus digunakan untuk amal di jalan Allah, atau diinvestasikan kembali dalam bisnis. ${ }^{3}$ Allah SWT berfirman dalam al-Qur'an Surah Al-Baqarah Ayat 219 bahwa: "... mereka menanyakan kepadamu (tentang) apa yang (harus) mereka nafkahkan: Katakanlah: Kelebihan (dari apa yang diperlukan) ..."Menurut Yusuf Ali, ayat ini menjelaskan bahwa kita harus mempergunakan harta harus sesuai dengan kebutuhan dan apabila ada kelebihan kita harus keluarkan untuk keperluan yang baik seperti dalam bentuk zakat, sedekah atau bantuan-bantuan dalam bentuk yang lain. (Dirjen Perkotdes, 2012)

Dengan demikian jelaslah bahwa sebagai seorang muslim sudah seharusnya mendapatkan dan mengeluarkan harta atau kekayaannya sesuai dengan caracara yang telah diatur dalam hukum syara'. Jika hal ini dilakukan tentunya akan memberikan manfaat baik di dunia maupun akhirat. Namun di sisi lain, pada zaman modern seperti sekarang ini banyak orang yang memperoleh kekayaannya dengan cara yang tidak diperbolehkan oleh hukum syara' seperti penipuan, perjudian, korupsi dan lainya yang sifatya menzalimi sesama umat manusia umumnya serta umat Islam khususya. Bentuk-bentuk usaha dalam memperoleh harta kekayaan seperti hal tersebut tadi berdampak pada pengeluaran yang akan digunakan untuk sesuatu tentunya tidak bermanfat bahkan mendatangka kerugian dunia dan akhirat. 
Banyak keterangan yang telah dijelaskan dalam Al Quran dan Hadits bagi mereka yang melakukan perbuatan-perbuatan tercela khususya berkenaan dengan kegitan memperoleh pendapatan (harta). Sebagai contoh, mereka yang melakukan korupsi akan medapatkan balasan dunia dan akhirat, di dunia mereka akan dihimpit permasalaha baik masalah keluarga dan hidup yang tidak nyaman. Selanjutnya, mereka akan medapatkan siksa yang teramat berat dari Allah SWT di akhirat nanti sebagaimana yang telah dijanjikan di dalam Al Quran.

Kehidupan masyarakat Martapura sudah sangat dikenal dengan ciri khas budaya Islam yang kental. Hal tersebut membawa dampak besar dalam pola pikir dan pergaulan yang ada terlebih lagi dalam memandang kehidupan. Pola kehkdupan ini boleh dikatakan sebagai wujud kearifan local yang khas. Kekhasan tersebut tentunya membawa kepada sifat dan wujud kebudayaan Islami khas masyarakat
Martapura. Di sisi lain kecendrungan mereka apabila dalam menghadapi permasalahan dalam kehidupan mereka akan meminta petunjuk kepada para alim ulama yang mereka panuti serta mempunyai ilmu agama yang tinggi dan mempunyai pengaruh di dalam Ilmu Agama khususnya di Martapura.

Kemudian berkenaan dengan pekerjaan kebanyakan masyarakat Martapura kalau dipandang dari sisi ekonomi, mereka mempunyai pekerjaan sebagai perdagang dan telah menjadi rutinitas keseharian mereka. Namu ada hal yang menarik dari dalam kehidupan mereka yaitu terkait dengan menuntut ilmu. Sebagai contoh, apabila jadwal pegajian dimana mereka menuntut ilmu mereka akan meliburkan kegiatan ekonomi mereka.

Dari beberapa informan yang telah ada, mereka beranggapan bahwa dengan cara seperti hal di atas, mereka mendapatkan keberkahan rezeki yang mereka usahakan setiap 
harinya. "Harta Barokah" dalam istilah mereka merupakan tujuan utama mereka dalam mencari harta. Jadi tidak semata-mata memandang materi melainkan keridhaan Allah merupakan tujuan utama mereka.

Kegitan ekonomi yang mereka lakukan serat dengan nilai ibadah. Hal tersebut dibuktikan dengan kegemaran mereka bersedeqah dan berinfak terlebih lagi dalam hal menuntut ilmu. Tidak salah jika orientasi kegitan ekonomi mereka mengarah kepada mencari ridha Allah SWT.

Para pengusaha yang boleh dikatakan sukses dan terkenal di Martapura mempunyai sifat darmawan, tidak hanya itu derajat ke-ilmuan agama mereka juga sudah diatas rata-rata kebanyakan masyarakat Martapura. Bermodal ilmu agama mereka membangun bisnis dan usaha dari dasar dan dikelola secara kekeluargaan serta turun temurun. Dari beberapa pegusaha yang telah peneliti wawancarai mereka beranggapan bahwa harta harus dialokasikan sesuai dengan yang diamanahkan oleh hukum syara'. Menurut mereka tujuan alokasi harta dalam Islam adalah: (Dirjenperkotdes, 2012)

1. Untuk mengharap pahala dan ridha Allah

Tercapainya kebaikan dan tuntutan jiwa yang mulia harus direlasikan untuk mendapat pahala dari Allah. Allah telah memberikan tuntunan kepada hamba-Nya agar menjadikan alokasi dana sebagai bagaian dari amal saleh yang mendekatkan seorang muslim kepada Tuhannya dan untuk mendapatkan surga dengan segala kenikmatan yang ada didalamnya.

2. Untuk mewujudkan kerjasama antar anggota masyakat dan tersedianya jaminan sosial.

Manusia hidup didunia ini ada yang ditakdirkan menjadi kaya dan ada yang miskin, di level pertengahan dan di level atas, itu semua tidak menjadi halangan untuk menjalin kerjasama 
antar manusia dalam semua bidang selama itu dalam kebaikan.

Pemberian nafkah akan mendidik jiwa untuk memiliki semangat

kebersamaan dan menjadikannya sebagai kesahajaan bersama Islam.

3. Untuk menumbuhkan rasa tanggung jawab individu, terhadap kemakmuran diri, keluarga dan masyarakat.

Islam telah mewajibkan adanya pemberian nafkah terhadap beberapa kelompok masyarakat yang termasuk dalam kategori saudara dan yang digolongkan sebagai saudara. Contoh: Dalam keluarga, laki-laki bertanggung jawab terhadap pemenuhan kebutuhan dan pemberian nafkah kepada seluruh keluarganya. Kita harus mempunyai tanggung jawab terhadap diri kita atas apa yang kita telah perbuat.

Ekonomi akan bergerak dan berputar disebabkan tumbuhnya perasaan yang didorong oleh kewajiban memberikan nafkah.

4. Untuk meminimalisir pemerasan dengan menggali sumber-sumber nafkah.

Media dan sumber nafkah sangat banyak dan beragam. Negara punya kewajiban untuk menjaganya, baik dengan membuka lapangan kerja, meningkatkan upah dan memenuhi kebutuhan orangorang yang kurang mampu. Orang yang memiliki jabatan khusus, ia harus memberikan gaji yang layak kepada karyawan. Seorang laki-laki memberikan jaminan kepada istri, anak, cucu, orang tua, dan kerabat lainnya.

5. Agar negara melakukan kewajibannya terhadap warga negara negara yang masih miskin. 
Nafkah

merupakan

kewajiban

negara

sebagaimana kewajiban itu

dipikulkan

ditangan

individu

untuk

menciptakan kemaslahatan

masyarakat. Peran negara

adalah sebagai berikut:

a. Menyediakan

lapangan kerja bagi

para pengganguran,

b. Memberiakan nafkah kepada golongan masyarakat yang tidak memiliki

sumber penghasilan serta tidak ada orang yang menjamin nafkah.

Golongan yang masuk kategori ini: orang sakit, gila,manula, anak kecil yang tidak punya keluarga, dll.

6. Menyediakan pendidikan dan sarana kesehatan secara gratis.

7. Penyediaan tempat tinggal untuk menampung orang- orang lemah,jompo,gila dan yang terganggu kesehatannya.

Kontrol penggunaan kekayaan dalam perspektif para pengusaha Muslim Martapura adalah sebagai berikut: (Dirjen Perkotdes, 2012)

1. Memberikan nafkah dalam medan yang bersifat syar'i agar mencapai tujuan agama dan orientasi dunia.

Tujuan agama: alokasi harta dalam bidang kebaikan untuk menghasilkan pahala akhirat. Contoh: shadaqah kepada fakir miskin, pembangunan masjid, rumah sakit, sarana pendidikan, dan menolong orang yang kelaparan, dll.

Orientasi dunia: sarana yang digunakan untuk mewujudkan kesejahteraan manusia. Contoh: pembangunan properti, perbaikan sarana transportasi, dan penyediaan pelayanan publik. 
2. Penggunaan harta untuk halhal yang dilegalkan, dianjurkan, atau yang diwajibkan. Pembelanjaan harta untuk hal-hal yang diharamkan termasuk kategori pemborosan harta. Contoh: pembelanjaan minuman keras, daging babi, prostitusi, dan segala bentuk penyebaran kerusakan lainnya.

3. Alokasi harta di jalan yang diperbolehkan hendaknya dilakukan sesuai dengan kebutuhan.

Dalil: QS. Al-Furqan: 67, QS. Al-Isra': 29 ๑ alokasi harta yang diperbolehkan harus dilakukan sesuai kebutuhan, tambahan ukuran kebutuhan dikategorikan berlebihan yang dilarang.

Macam-macam alokasi harta:
a. Alokasi itu dalam bidang yang sesuai dengan keadaan

pelaku dan jumlah harta yang dimiliki.

b. Dalam bidang yang jelas tidak sesuai dengan kemampuan diri:

1. Untuk

menghindari

adanya bahaya (baik yang terduga maupun yang tak terduga). Hal ini diperbolehkan.

2. Yang tidak termasuk kategori itu. Mayoritas ulama mengkategorikan ini sebagi berlebihan.

3. Penggunaan harta berbanding lurus dengan sumber pemasukan (pekerjaan) agar tidak terbebani 
da menjadi para penghutang.

Banyaknya belanja untuk keperluan dunia dimakruhkan, namun jika untuk kebutuhan mendesak seperti ada tamu, hari raya, atau resepsi.

Di sisi lain, mereka memandang ikhtiar yang mereka lakukan dalam aktivitas ekonomi terkait memperoleh harta kekayaan, tidak lepas dari peran dan hasil kerja para karyawan. Mereka mempunyai padangan tersendiri tetang mengelola karyawan. Upah yang diberikan kepada para pegawai dan pekerja sebagai ganti kewajiban yang telah ditunaikan merupakan satu kewajiban. Ketika menyelesaikan pekerjaan, para pegawai dan pekerja berhak untuk mendapatkan gaji yang layak sesuai dengan kebutuhan hidup diri dan orang yang menjadi tanggungan mereka. Sebagimana pendapat mereka bahwa Nabi Muhammad memerintahkan untuk segera memberikan gaji kepada karyawan setelah pekerjaannya diselesaikan. Kesengajaan dan kelalaian terhadap hak karyawan merupakan bentuk dari dorongan nafsu belaka sehingga berimbas pada siksa yang paling pedih nantinya di akhirat, Sesuai dalam firman Allah dalam hadis qudsi:

"Tiga orang yang Aku musuhi di hari kiamat; Orang yang memberi atas nama-Ku, kemudian diminta lagi, orang yang menjualbelikan orang yang merdeka kemudian memakan harganya, dan orang yang mempekerjakan karyawan kemudian ia mengambil seluruh haknya dan tidak sedikitnya memberinya sesuatu."

Sebagaimana yang telah dipaparkan di atas, bahwa para pengusaha muslim Martapura mempunyai konsep yang selaras dengan konsep syara'. Namun tentunya perlu juga kita selaraskan dengan pandagan pengeloan Harta dalam pandagan ekonomi syariah. Sebagaimana telah dipaparkan sebelumnya bahwa manajemen pengelolaan harta kekayaan tidak lepas dari hal yang dimana kita mempunyai tanggung 
jawab terhadap diri kita dan orangorang di sekitar kita maka, dirumuskan bahwa distribusi dalam konsep maajemen pengelolaan harta mempunyai tujuan untuk mendapatkan keberkahan maka harus memperhartikan pada:

1. Prioritas Pemanfaatan Harta

2. Prinsip Halal \& Thayyib Dalam Konsumsi

3. Menghindari Tabdzir dan Israf

4. Kesederhaan (Moderat)

5. Kosumsi Sosial

6. Pemanfaatan Harta Untuk Masa Depan

Ke enam konsep inilah yang menjadi tolak ukur dalam Manajemen Pengelolaan Harta kekayaan pada Pengusaha muslim di Martapura. Walaupun dalam keseharian mereka di sibukkan dengan permasalahan keduniaan mereka tetap berpegang teguh kepada nilai-nilai keimana sehingga mereka tidak lalai dalam menerima amanah dari Allah untuk mengelola harta.

\section{KESIMPULAN}

1. Islam memberikan peluang besar kepada umatnya untuk memajemen harta. Namun perlu ada beberapa hal yang harus diperhatikan dan di jaga. Yaitu berkenaan alokasi penggunaan harta dan bagaimana harta tersebut bisa menjadi sarana untuk meningkatkan iman kepada Allah SWT.

2. Pola yang dilakukan oleh para pengusaha Muslim di Martapura tidak lepas dari tuntunan yang telah dijabarkan dalam hukum fiqih muamalah. Yaitu dengan tidak merasa bahwa pemilik harta tersebut adalah siapa yang mendapatkanya melaika itu adalah perantara semata untuk menyalurkan kepada siapa yang berhak menerimanya. Kemudian juga konsep mereka dalam memanajemen harta adalah pondasi utamanya adalah mengharapkan ridho Allah SWT semata. Hal inilah yang bisa medatangkan 
keberkahan di mata pengusaha muslim martapura.

\section{DAFTAR PUSTAKA}

Abdullah Lam Ibn Ibrahim, Fiqih Finansial, Solo: Era Intermedia, 2015.

Al-Syatibi, Al-Muwāāaqāt fi Usūl alSyari'ah, (Bairut: Dār alMa'rifah 1415H/1994M).

Asy Saibani, Al Ikhisab fir Rizqil

Mustathab, Muthabi Offcet, t.k, tt.

Direktorat Jenderal Perkotaan dan Pedesaan, Data statistik Deputi bidang pengembangan regional dan otonomi daerah, tahun 2012.

Erwandi Tarmizi, Harta Haram Muamalat Kontemporer, Bogor: PT. Berkat Mulia Akbar tahun 2013.

Ibnu Katsir, Tafsir Ibnu Katsir, Muassasah Ar Risalah, tk., 2000.

Ibnu Sinā, Kitab al-Siyāsah. ed. Louis Ma'luf, in Louis Cheikho et. al, Maqālat Falsafiyyah Qadīmah li Ba'di Masyāhīrih Fālāsifah al'arab Muslimin wa Nasara, Beirut: al-Matba'

al-
Kātsūlìkiyyah lil Abāi alyasū'iyyin, 2011.

Ibnu Taimiyah, Majmu'ul Fatawa, Darul Makrifah: tt.

Ismāil Rājī al Fārūqi, Al Tawhid: Its Implication for Thought and Life, IIIT: USA, 1998.

Jafril Khaliil, Jihad Ekoomi Islam, Depok: Gramata Publishig, 2010.

Jaribah bin Ahmad Al Haritsi, Fiqih Ekonomi Umar bin Khattab,Jakarta: Khalifa, 2006.

Norman K. Denzin dkk, Hand Book Of Qualitative Researsch, Pustaka Pelajar: Yogyakarta, 2009.

Qur'an, Surah Al-Baqarah: Ayat 219, Text, Translation and Commentary by Abdullah Yusuf Ali, Dārul Arābiyyah: Beirut.tt.

System Ekonomi prinsif dasar Islam (fundamental of Islamic Economic System), Pranadamedia Group, Jakarta :Cetakan Ke 3 Januari 2016.)

Tim Pusat Pengkajian dan Pengembangan Ekonomi Islam UII, Ekonomi Islam, Yogyakarta: Rajawali Press, 2008. 